\title{
Sensitive Analysis of Soft Crab Meat on Paraná Coast- Brazil
}

\author{
${ }^{1}$ Adilson Anacleto, ${ }^{2}$ Clarice Luiz do Rosário, ${ }^{3}$ Gustavo França da Costa, ${ }^{4}$ Leonardo de Almeida Ladevig, ${ }^{5}$ Suzan \\ Alves Maia
}

${ }^{1}$ Administration Department, Associate Professor, Paranaguá Campus/Professor from the Interdisciplinary Postgraduate Program - Society and Development PPGSeD, Campo Mourão Campus, State University of Paraná, Paraná, Brazil.

${ }^{2,3,4,5}$ Administration Department, Scientific Initiation Researcher, State University of Paraná, Paranaguá, Paraná, Brazil.

Correspondence Author: Adilson Anacleto, Administration Department, Associate Professor, Paranaguá Campus/Professor from the Interdisciplinary Postgraduate Program - Society and Development-PPGSeD, Campo Mourão Campus, State University of Paraná, Paraná, Brazil..

E-mail:- Adilson.anacleto@unespar.edu.br

Received date: 10 January 2019, Accepted date: 25 February 2018, Online date: 28 February 2019

Copyright: () 2019 Adilson Anacleto et al, This is an open-access article distributed under the terms of the Creative Commons Attribution License, which permits unrestricted use, distribution, and reproduction in any medium, provided the original author and source are credited.

\begin{abstract}
Fishing is an activity with a significant economic importance in Paraná Coast. In the last decades, the soft crab fishery has been reported as a relevant income alternative in small fishing communities in that region. Among the several types of catching this crustacean there are the soft crab capture along with the trawling of shrimp nets and also in a handcraft way with the use of cages. However, despite the relevance of the activity to the more distant fishing communities, there are few and sparse studies on the quality of the soft crab meat offered in the market. Thus, this study aimed to obtain data on the preference of consumers for the appearance, color, aroma and flavor of the soft crab meat through sensory analysis, with the objective of producing information for small fishermen in order to increase the market competitiveness for this product. Four samples from the most important producing regions in Paraná Coast were used in a blind test. All samples were prepared in a similar and concomitant manner. The analysis was applied to 20 individuals, with the possibility of eating one of the four samples each one at a time and then give the grade, proceeding to the next sample, until all grades were properly attributed. The homogeneity of the variances was determined by the Bartlett test, and for the comparison of scores averages assigned in the sensory evaluation, the Tukey test was used at the 0.05 level of probability. The study concluded that the samples evaluated do not differ statistically from one another in the blind test in terms of appearance, color and aroma, but the taste of the soft crab meat is the main factor that influences this product consumption, and in this case showed differences between the samples evaluated. The soft crab meat caught in cages when evaluated in the blind test received the best grades when compared to the other samples analyzed, named as soft crab meat obtained from canoes and soft crab meat obtained from deep-sea fishing. The capture system in relation to the size of the crustaceans, the refrigerated conservation form and the beneficiation system may be the main influencing factors in the increase of the soft crab meat quality among the evaluated samples.
\end{abstract}

Key words: Consumer perception. Trawling. Handcraft fishing. Consumer Satisfaction.

\section{INTRODUCTION}

The sea fishing in Paraná has been showing highly complexity and being composed of a wide range of aquatic environments and a wide variety of catch practices that may vary according to where the fisherman is and his/her cultural origin (Andriguetto Filho, 2002).

Among the types of species caught in Paraná Coast for the purpose of income generation, it is highlighted the soft crab fishing, which shows a high demand among consumers, especially vacationers. Soft crabs are crabs of the Portunidae family with relevant ecological and economic importance in Paraná Coast. In the Paranaguá Bay - PR is reported the presence of the genus Callinectes (Gaspar, 1981). The species most captured in Paraná Coast are: C. sapidus (Guaçú) and C. danae (Mirim), being the last one the most common species found in coastal bays.

The quality obtained linked to the low cost of capture and the product high demand, has caused a gradual increase in the number of people practicing the soft crab fishing for commercialization (Anacleto, 2018).

Among the several forms of soft crab capture, it is highlighted the soft crab fishing with cages, a type of catch developed on the islands of Paraná Coast, and nowadays it is possible to be found in other Brazilian regions.

The soft crab fishing with cages has a different profile than shrimp trawling, which is only extractive, catching animals of all sizes and genera. In the case of cage fishing, Baptista-Metri et al. (2015) say that this kind of fishing has an extractive character, 
Citation: Adilson Anacleto, et al., Sensitive Analysis of Soft Crab Meat on Paraná Coast- Brazil. Australian Journal of Basic and Applied Sciences, 13(2): 55-59. DOI: 10.22587/ajbas.2019.13.2.7

but can also be classified as selective, because fishermen at the moment of removing the crustaceans from the trap have the possibility of separating the adult ones from the young and the female ones, which are returned to the sea in order to not interrupt the reproduction cycle of the species.

Despite its wide consumer acceptance, there is a lack of basic information related to this product consumer preferences (Baptista-Metri et al., 2015, Anacleto et al., 2016). According to Kotler and Keller (2012) and Churchill and Peter (2012) before understanding the preference of the consumer it is necessary to have the comprehension of stimulus that leads the consumer to consume, thus leading he/she to the decision of purchasing, in this context, the consumer suffers influences from social, cultural, personal and psychological factors, as well as situational, that comes from physical and mental circumstances, such as sensation at the time of purchasing.

In this way, the market research, especially those related to what the consumer thinks and how he/she behaves, is essential in order to know which are the factors that generate satisfaction or dissatisfaction in the purchase process, and in this way act in the mitigation of the uncertainties that occur in relation to the offer of products considered as embryonic in the market (Blackwell et al., 2006), as the case of the trade of the soft crab meat caught with cages described by Anacleto (2018).

The detailed sensory knowledge is important in order to have the quality control and the evaluation of the changes that can contribute to the improvement of the product favoring the insertion of the product in more competitive markets and avoiding the clash with substitute very competitive products as fish and shrimps (Campos et al., 2017). Through the sensorial analysis, it can be understood the complex sensation that results from the interaction of the senses in order to analyze the different organoleptic characteristics and thus, make a selection of the best process with the objective of determining the level of specific quality of the soft crab meat that meets the consumer preference.

Few studies in Brazil were carried out on the sensorial quality of crustaceans that could result in the understanding of consumer demands. According to Anacleto et al. (2011), the sensorial analysis may represent an alternative that the typical products from Paraná Coast could show general improvement in their quality, so that they could meet the consumer's expectations, thus increasing the consumption. In this context, this study aimed to use to use sensory analysis in order to obtain data on consumers' preference related to the color, aroma and taste of soft crab meat, with the aim of producing information for small fishermen, then they can increase the competitiveness of the product in the market.

\section{MATERIALS AND METHODS}

The study was developed similarly to that proposed by Carneiro et al. (2010) and Anacleto et al. (2017), the type of research used is classified as exploratory-descriptive, being the organization process of sensory evaluation according to that proposed by Anacleto et al. (2011).

It was adopted as (comparative) witness, the soft crab meat caught in Vila São Miguel because this place is the greater producer of soft crab meat caught with cages. The other soft crab meat samples used in the experiment were classified by Anacleto (2018) as traditional, because their origin was from shrimp trawls, and they were respectively acquired in the municipal markets from Guaratuba, Matinhos and Paranaguá, which are the largest commercial centers for soft crab meat in Paraná.

All soft crab meats were purchased from fishermen accredited in licensing agencies for the fishing and processing of soft crab meat, thus ensuring the provenance of the samples tested. In total, four samples were randomly acquired in the local markets (Table 1).

Table 1. Samples evaluated in the sensory analysis of soft crab meat obtained from producers in Paraná Coast.

\begin{tabular}{|c|c|c|}
\hline Sample & Producing region & Characteristics \\
\hline Sample 1 & Paranaguá (Vila São Miguel) & Soft crab meat caught with cages \\
\hline Sample 2 & Paranaguá & Soft crab meat caught with trawl in Paranaguá Bay \\
\hline Sample 3 & Guaratuba & Soft crab meat from shrimp trawling \\
\hline Sample 4 & Matinhos & Soft crab meat with canoe trawling \\
\hline
\end{tabular}

The preparation of the samples occurred in an equally way, regarding to the quantity of the soft crab meat, the cooking time and the amount of seasoning used, emphasizing that all the samples were prepared concomitantly.

The sensorial test as proposed by Guaglianoni and Faria (2011) was carried out with a voluntary recruitment of people who showed availability and interest in participating. It was an essential criterion that volunteers were over 18 (eighteen) years old and had preferably consumed soft crab meat in any form in the last 6 (six) months.

From the recruitment, the judges were asked to complete a semi-structured questionnaire before the beginning of the sensorial evaluation in order to obtain information about the factors that influence the consumption of soft crab meat, as well as to characterize the sample in relation to the monthly income, gender, frequency of purchase and average consumption. The sensorial test consisted in evaluating the sensorial characteristics of color, appearance, flavor and aroma of the soft crab meats, characterizing then the sampling.

The samples used in the sensorial evaluation were previously distributed in small glasses with approximately 40 grams in each one. The participants had a glass of water to clean the palate in order to be able to taste a new sample. After each test the grades were assigned and recorded on the score sheets by the volunteer evaluators themselves.

The packages with the meat did not present indications that could reveal the origin of the evaluated sample which characterized a blind test. The volunteer judges received a card containing four organoleptic characteristics: appearance, color, aroma and flavor. With this, the Likert scale was used, with ten points for evaluation of the degree assigned by the judge. 
Citation: Adilson Anacleto, et al., Sensitive Analysis of Soft Crab Meat on Paraná Coast- Brazil. Australian Journal of Basic and Applied Sciences, 13(2): 55-59. DOI: 10.22587/ajbas.2019.13.2.7

The questionnaires were all applied on September 17, 2018, with 20 participants, performing one blind test for each one of the 4 (four) samples per individual. The homogeneity of the variances was determined by the Bartlett test, and for the comparison of the score averages assigned in the sensory evaluation, the Tukey test was used at the 0.05 level of probability.

The results were evaluated using the program SPSS (version 16)

\section{RESULTS}

The study revealed that there were no significant differences in consumption among the genders with an average of 4.28 times per year, with the average age of the consumers being around 24 years old. The study also reported data similar to that observed by Anacleto et al. (2016) which there was no change in consumption due to age, gender or family composition.

Specifically related to appearance, color and aroma of the samples tested, there were no significant statistical differences between the scores attributed by the judges (Table 2), however, it was observed that the aroma variance presented the lowest average scores when compared to the appearance and color.

Table 2. Sensory evaluation of soft crab meat in Paraná Coast $(n=80)$.

\begin{tabular}{|c|c|c|c|}
\hline Sample & \multicolumn{3}{|c|}{ Average score of the evaluated samples } \\
\hline Sample 1 & Appearence & Color & Aroma \\
\hline Sample 2 & $7,85^{\mathrm{a}}$ & $7,85^{\mathrm{a}}$ & $6,50^{\mathrm{a}}$ \\
\hline Sample 3 & $7,65^{\mathrm{a}}$ & $7,75^{\mathrm{a}}$ & $6,55^{\mathrm{a}}$ \\
\hline Sample 4 & $7,85^{\mathrm{a}}$ & $7,75^{\mathrm{a}}$ & $6,80^{\mathrm{a}}$ \\
\hline
\end{tabular}

Averages followed by the same letter do not differ statistically from each other (Tukey $\mathrm{p}<0,05)$.

The taste of the soft crab meat is considered one of the main factors responsible for consumption (Table 3), in this aspect the samples of soft crab meat caught with cages and those from the catch with large fishing boats from Guaratuba received the best scores, and although they did not vary among themselves, they were statistically different from the others.

Table 3. Evaluation of the taste of the soft crab meat samples in Paraná Coast $(n=80)$.

\begin{tabular}{|c|c|c|c|}
\hline Sample & \multicolumn{3}{|c|}{ Taste } \\
\hline Sample 1 & Average & Standard deviation & Variance \\
\hline Sample 2 & $8,25^{\mathrm{a}}$ & 1,33 & 1,77 \\
\hline Sample 3 & $7,95^{\mathrm{ab}}$ & 1,87 & 3,51 \\
\hline Sample 4 & $8,01^{\mathrm{a}}$ & 1,48 & 2.14 \\
\hline
\end{tabular}

Averages followed by the same letter do not differ statistically from each other (Tukey $\mathrm{p}<0,05)$.

The comparison between the organoleptic properties in general context revealed that the smell received the lowest grades in the evaluation.

\section{DISCUSSION}

The experimentation process of a new product consists of phases initially associated to the organoleptic characteristics. The first of these phases is cognitive, when the consumers based on their previous experiences decide whether he/she agree to advance or not in the experimentation. At this stage the appearance of a product constitutes as the first barrier in the process, and also connected to appearance another evaluative parameter is the coloration. Thus, in an inseparable way appearance and coloring merge into a vision process, and if there are no previous negative experiences even of different products and foods, the possibility of experimentation arises.

Thus, the factor view is significant in the decision process for the consumption. According to Kotler and Keller (2012), the process of increasing the sales of a product deserves care in the presentation form and arrangement of the products as a way to awaken the organoleptic property related to the vision.

At this stage, it figures the relevance of the use of organoleptic properties as decision factors in consumption, regardless of the type of product. Specifically related to the appearance and color, for soft crab meat, since there were no significant changes and the scores assigned by the judges were high, then classified as satisfactory. The consumer naturally advances his assessment regarding to another organoleptic property with equal importance, the aroma.

The aroma among the evaluated items was the one that received the lowest average scores attributed in the blind test among the judges. Thus, in this context according to Campos et al. (2017) technological improvement and quality control of fish production should occur, as in the case of soft crab meat in order to improve the quality of the aroma, since in all samples the assigned scores did not reach the pre-established minimum value of 70 or more. According to Campos et al. (2017) the first possible ways to improve the aroma of the product could occur precisely in the phase of beneficiation by the fishermen, as said by Amaral and Freitas (2013) the aroma of the fishes is associated to their freshness that has great importance for being the main criterion that determines their acceptance by consumers. Then extrinsic factors such as transport and storage, or even the time between the fishing and the processing could significantly improve the aroma. 
Citation: Adilson Anacleto, et al., Sensitive Analysis of Soft Crab Meat on Paraná Coast- Brazil. Australian Journal of Basic and Applied Sciences, 13(2): 55-59. DOI: 10.22587/ajbas.2019.13.2.7

Germano and Germano (2008) and Amaral and Freitas (2013) emphasize that the degradation of fishes is related to the type of catch, transportation and storage and that special care is needed, especially the fast cooling, besides the hygienic conditions of conservation and manipulation. In this context, the evaluation of freshness has great importance during fish storage, mainly because they are very perishable. Perishability alters the aroma of fish in general, including soft crab meat. Fishermen should then create more agile processes that limit the time between catch, expenditure and processing, factors that could improve the quality of the aroma.

Other palliative actions could be carried out by merchants who sell the processed products, that are reported by the local culture as washing the soft crab meat and then left in the seasoning to be used in the final product for a few minutes for total absorption, thus being able to soften the aroma (Campos et al., 2017).

The flavor was the organoleptic characteristic that presented the greatest variation in the blind test attributed by the judges (Table 3). The cognitive phase related to the taste is the moment in which the consumer processes the information that results in the approval or not of the consumption. Yet at this stage, the consumer considers other dimensions beyond the organoleptic ones, such as emotional, psychological and cultural. The positivity of this phase then results in experimentation and has influence on the formation of affective loyalty, derived from a positive attitude. The repetition of this set of situations related to the product consumed, and that meets the desires and expectations of consumers, extends the limits of consumer loyalty. Thus, the product consumption loyalty can be determined as the degree of commitment that the consumer has, in the sense of continuing to buy the same product in the future.

The behavioral response resulting from a process elaborated on available alternatives based on cognitive, affective, evaluative and dispositional factors are the classic components of an attitude, and the relevance of the "taste" or flavor can be classified as essential to the success of these questions.

Specifically, concerned to the trade of soft crab meat, the flavor may also be linked to the catching and processing system. The samples 2 and 4 come from canoe-type boats.

The canoes according to Chaves and Robert (2003) are small boats traditionally built of wood, and have a length of 6 to 10 meters, with a center motor with a force of 11 to $24 \mathrm{HP}$, being constructed from a single log excavated wood with hooked bottom, $\mathrm{V}$-shaped. There is also in a smaller quantity of fiberglass canoes with 8 to 9 meters and center motor with force of 11 to $24 \mathrm{hp}$; same form as the previous type, but made with synthetic resin and fiberglass and also V-shaped bottom. Paraná Coast still has many canoes used by fishermen moved by human traction (rowing) or sailing.

The canoes in the most of cases are characterized by the system called "fishing from sun to sun", which means that the fisherman leaves with the first rays of the sunrise, put the fish catch nets and at the end of the day at the sunset, collects the nets and returns to his residence, or even the fishermen at sunset throw their nets and later collect at the next sunrise.

The boats of this type of fish catch are often with no suitable places for accommodation of the fishes with system of cooling with ice or refrigerator. The adoption of this fishing system may be related to the low notes attributed to the aroma and also to the flavor, since as already explained by Amaral and Freitas (2013), all these factors affect the quality of the products.

Another factor that may have been influenced these samples, besides the fishing mechanisms used by the local fishermen is those related to the commercialization, it may be that these fishermen actually capture the shrimp in the extractive fishing, in this system they use the net trawls to fish the shrimps and it occurs the capture of the soft crab of the most diverse sizes along with the shrimps, which is known to make it difficult to remove the soft crabs from the net, appearing small pieces of animal cartilage or carapace, which may have affected the quality and consequently the scores related to the taste in the blind test.

On the other hand, the samples obtained in the regions of Vila São Miguel and Guaratuba, got high scores in the blind test evaluation.

The sample number three, similarly to the one mentioned previously, the soft crabs also were come from the fishing of shrimp in the oceanic coast, in this case are used boats with sizes very much greater than the canoes. Offshore fishing boats are characterized by having refrigerated fish storage system for many days. In this context, traditionally at the time of shrimp expenditure, fishermen also select the crabs and soft crabs and place them in cooling chambers where the they can remain alive until slaughter and processing.

The sample number one was related to the soft crabs fishing carried out with cages and that received the highest scores in the blind test by the judges, the higher quality of taste compared to the other samples tested may also be related to the adopted catch system.

The fishermen go to the fishing grounds where the cages are thrown to the sea, where they remain for a period of approximately one day. The cages worked as a kind of trap in which the fisherman placed baits of fish, what attracted the soft crabs in the food searching, and once they entered at the "trap," the crustaceans could not get out of it (ANACLETO, 2018). And still according to Anacleto (2018) the capture of soft crabs with cages in the fisherman's approach generates a product of excellent quality due to selective capture, the soft crabs remain alive and in the removal of the crustaceans from the trap, the fishermen separate the young ones from the adult ones and the female that are returned to the sea so that the reproduction is not interrupted, thus the time between the capture and the preparation of the meat is short. All these factors associated to the capture system may be the cause of the higher grades attributed to this kind of soft crab meat.

\section{FINAL CONSIDERATIONS}

The evaluated samples did not differ statistically from one another in the blind test in terms of appearance, color and aroma, but the taste of the soft crab meat is the main factor that influences the product consumption, and in this case showed significant statistical differences among the evaluated samples. 
Citation: Adilson Anacleto, et al., Sensitive Analysis of Soft Crab Meat on Paraná Coast- Brazil. Australian Journal of Basic and Applied Sciences, 13(2): 55-59. DOI: 10.22587/ajbas.2019.13.2.7

The soft crab meat caught with cages when evaluated in blind test received the best scores when compared to the other samples analyzed, so the soft crab meat came from canoes capture and soft crab meat obtained from fishing by offshore boats.

The capture system in relation to the size of the crustaceans, the refrigerated conservation form and the beneficiation system may be the main influencing factors in the quality increase the soft crab meat among the evaluated samples.

\section{REFERENCES}

Amaral, G.V., Freitas, D.G.C. 2013. Método do índice de qualidade na determinação do frescor de peixes. Ciencia Rural, 43(11):2093-2100.

Anacleto, A. 2018. Cadeia produtiva da pesca de siri com gaiolas no litoral paranaense: características, implicações sociais, ecológicas e perspectivas econômicas. In: Sulzbach, Mayra Taiza; Archanjo, Daniela Resende; Quadros, Juliana. (Org.). Litoral do Paraná: Território e Perspectivas. Volume III: Dimensões de desenvolvimento. 1ed. Rio de Janeiro: Autografia, 2018, v. III, p. 178-207.

Anacleto, A., Jesus, P.N.F., Ramos, R.A.S. 2017. Profile and behaviour of orchids consumer in Paraná coast - Brazil. Australian Journal of Basic And Applied Sciences, 11(1):32-40.

Anacleto, A., Broetto, B., Xavier, F.P., Ferreira, K.B.S. 2016. Retail trade of caged crabmeat (Callinectes sp) on the coast of Paraná - Brazil. Business Management Dynamics, 5(6):77-86.

Anacleto, A., Rothbart, M., Fiorentin, N.M., Souza, P.A., Prestes, R.K. 2011.Avaliação do consumo de palmito de pupunha no litoral do Paraná. Scientia Agraria. 12(1):25-29.

Andriguetto Filho, J.M. 2002. Sistemas técnicos de pesca no litoral do Paraná: caracterização e tipificação. In: Raynaut, C. Desenvolvimento e Meio Ambiente: em busca da interdisciplinaridade. Curitiba: EdUFPR, p.213-233.

Baptista-Metri, C., Anacleto, A., Gonçalves, T.P., Calado, A.M., Rosário, É.S., Pontes, M., Neves, P.R. 2015. Extrativismo do siri com gaiolas no litoral paranaense: implicações socioeconômicas. Revista Sodebras, 10(1):9-14.

Blackwell, R.D., Engel, J.F., Miniard, P.W. 2006. Consumer Behavior, South Wester, p.832.

Campos, A. M., Anacleto, A., Bianca D.N. 2017. Retail trade of fishes in natura in Paraná Coast - Brazil. Business Management Dynamics, 6(1): 2-8.

Chaves, P.T., Robert, M. C. 2003. Embarcações, artes e procedimentos da pesca artesanal no litoral sul do Estado do Paraná, Brasil. Atlântica, 25(1):53-59.

Carneiro, J.D.S.; Minim, V.P.R., Chaves, J.B.P., Silva, C.H.O.; Regazzi, A.J. 2010. Opiniões e atitudes dos consumidores em relação a embalagens e rótulos de aguardente. Ciência e Tecnologia de Alimentos, 30(3):669-673.

Churchill, G.A., Peter, J. P. 2012. Marketing: criando valor para o cliente. São Paulo: Saraiva.

Gaspar, M.H. 1981.Contribuição ao estudo biológico do siri Callinectes danae Smith, 1869 (Decapoda-Portunidae) do Rio Itiberê (Paranaguá-Paraná). Dissertação (Mestrado) - Universidade Federal do Paraná, 150p

Germano, P.M.L., Germano, M.I.S. 2008. Higiene e vigilância sanitária de alimentos. 3.ed. Barueri: Manole, 986p.

Guaglianoni, D.G., Faria, J.B. 2011. Análise sensorial, um estudo sobre procedimentos estatísticos e número mínimo de julgadores. Alimentos e Nutrição, 22(1):21-25.

Kotler, P. 2012. Administração de Marketing: Análise, Planejamento, Implementação e Controle. 10. ed. São Paulo: Atlas. 